\title{
Functioning of Salt Tolerant Anabaena variabilis and Nostoc calcicola Strains in Salt Stress, Destructors of Hexachlorocyclohexane (HCH) in Saline Conditions
}

\author{
Gulchekhra Khakimovna Kadirova \\ Institute of Microbiology, Uzbekistan Academy of Sciences, Tashkent, Uzbekistan \\ Tel: 998-981-237-176 E-mail: kadirovagul@mail.ru \\ Kim Andrey Andreevich \\ Institute of Nuclear Physics, Uzbekistan Academy of Sciences, Tashkent, Uzbekistan \\ Tel: 998-712-695-210 E-mail: aakim@globalnet.uz
}

Lorenz Adrian

Department Isotope Biogeochemistry

Helmholtz Centre for Environmental Research, - UFZ, Leipzig, Germany

Tel: 349-341-235-1435 E-mail: lorenz.adrian@ufz.de

Rasulov Bakhtiyor (Corresponding author)

Institute of Genetics and Plant Experimental Biology

Uzbekistan Academy of Sciences, Tashkent, Uzbekistan

Tel: 998-909-422-892Ｅ-mail: bakhtiyor_1980@mail.ru

Received: November 23, 2011

Accepted: January 19, 2012 Published: March 1, 2012

doi:10.5539/enrr.v2n1p63

URL: http://dx.doi.org/10.5539/enrr.v2n1p63

\begin{abstract}
We investigated the degradation of hexachlorocyclohexane $(\mathrm{HCH})$ in soil by two cyanobacteria isolates Anabaena variabilis $\mathrm{N} 21$ and Nostoc calcicola $\mathrm{N} 25$ under high concentrations of $\mathrm{NaCl}$. After four months of incubation cultures in saline soils with $4 \% \mathrm{NaCl}$ decreased $\mathrm{HCH}$ concentrations considerably from $2 \mu \mathrm{g} / \mathrm{g}$ soil to $14 \mathrm{ng} / \mathrm{g}$ soil, representing $1 \%$ of the introduced $\mathrm{HCH}$. In pure cultures $1 \mathrm{M} \mathrm{NaCl}$ was not lethal but significantly changed the morphology of the cyanobacteria. Enzyme assays for aldehyde oxidase and xanthine oxidase indicated the overexpression of xanthine oxidase in Nostoc calcicola N25 under salt-stress. Our results indicate that the strains can be used as biopreparations for bioremediation of salt-affected soils polluted with persistent chlororganic compounds often found in Uzbekistan soils.
\end{abstract}

Keywords: Cyanobacteria, 1,2,3,4,5,6-hexachlorocyclohexane $(\gamma-\mathrm{HCH})$, Aldehyde oxidase, Xanthine dehydrogenase, Biotransformation, Salinity

\section{Introduction}

Lindane, technically 1,2,3,4,5,6-hexachlorocyclohexane $(\gamma-\mathrm{HCH})$, is a widely distributed organochlorine pesticide in diverse environmental compartments. The production of lindane results in the generation of large quantities of waste $\mathrm{HCH}$ isomers (mainly $\alpha$-, $\beta$ - and $\gamma$-isomers). All these isomers are toxic and have a long-range environmental transport potential. $\mathrm{HCH}$ biodegradation by aerobic and anaerobic microorganisms has been documented in various environments. HCH-degrading microorganisms such as fungi, cyanobacteria, and anaerobic and aerobic bacteria have been widely investigated (Phillips et al., 2005). Also, the genes involved in $\mathrm{HCH}-$ degradation have been studied. For example, a detailed characterization of the pathway for aerobic $\mathrm{HCH}$ 
degradation by Sphingomonas paucimobilis strain UT26 showed the involvement of lin genes encoding the HCH biodegradation pathway (Nagata et al., 1999). These lin genes have also been found and studied in several other HCH-degrading bacteria (Kumari et al., 2002; Thomas et al., 1996). However, when applying living cells for the in situ biodegradation of $\mathrm{HCH}$ in the field, in most cases, the number of introduced cells decreases shortly after inoculation due to both abiotic and biotic stresses (Alexander, 1999). Abiotic factors controlling the survival of introduced microorganisms include moisture content, temperature, salinity, $\mathrm{pH}$, soil texture, oxygen concentration and nutrient availability (Phillips et al., 2005; van Elsas et al., 1986). Biological factors also play an important role for the survival of introduced cells (Lypez-Gomollyn et al., 2009, von Elsas and Heijnen, 1990). An approach to overcome some of the problems associated with microbial survival after inoculation is the use of protective carriers, for example the immobilization of cells by encapsulation (Mertens et al., 2006, van Veen et al., 1997).

In Uzbekistan, a considerably high portion of the arable land is both, contaminated with biocides used for crop protection, such as $\mathrm{HCH}$, and burdened with high salinity as a result of extensive irrigation with river waters during the last century (Forkutsa et al., 2009; Shirokova et al., 2000). In addition, HCH contaminations in Uzbekistan are often diffuse and spread over large areas so that chemical and/or physical remediation methods appear economically unfeasible. We therefore evaluate the application of cyanobacteria for the remediation of $\mathrm{HCH}$ contaminated saline soils. The efficiency of remediation of $\mathrm{HCH}$-contaminated and salt-affected soils in Uzbekistan depends to a large extend on the ability of cells to survive under high-salt conditions. It is important to know in advance of remediation efforts how well an $\mathrm{HCH}$ degrading strain is adapted to high-salt conditions to predict the probability of survival in the natural habitat. The aim of the current study was to investigate growth and biodegradative capacities of strains Anabaena variabilis N 21 and Nostoc calcicola N 25 under high-salt conditions. For that, we compared growth in low-salt versus growth in high-salt media. In addition, we studied the expression of aldehyde oxidase and xanthine dehydrogenase, which are synthesized in high concentrations of $\mathrm{NaCl}$.

\section{Materials and Methods}

\subsection{Microorganisms}

Two cyanobacterial strains of our culture collection were selected for the present study. The two strains Anabaena variabilis N 21 (Uzb1) and Nostoc calcicola N 25 (Uzb2) were previously isolated from HCH-containing, salt-affected soils from Kashkadaryo and Syrdaryo Province in Uzbekistan, respectively (Kadirova et al., 2007). Initial classification of the isolates was done by classical methods.

\subsection{Cultivation}

The medium used to grow the strains was nitrogen-free "M" medium with following chemical ingredients (g/l): $\mathrm{MgSO}_{4} \cdot 7 \mathrm{H}_{2} \mathrm{O}-0.25 ; \mathrm{CaCl}_{2} \cdot 2 \mathrm{H}_{2} \mathrm{O}-0.0238 ; \mathrm{Na}_{3} \mathrm{C}_{6} \mathrm{H}_{5} \mathrm{O}_{7} \cdot 5.5 \mathrm{H}_{2} \mathrm{O}-0.165 ; \mathrm{K}_{2} \mathrm{HPO}_{4}-0.04$; trace elements -1 $\mathrm{ml} / \mathrm{l}:\left(\mathrm{FeCl}_{3} \cdot 6 \mathrm{H}_{2} \mathrm{O}-0.002 ; \mathrm{ZnSO}_{4} \cdot 7 \mathrm{H}_{2} \mathrm{O}-0.222 ; \mathrm{CuSO}_{4} \cdot 5 \mathrm{H}_{2} \mathrm{O}-0.079 ; \mathrm{MnCl}_{2} \cdot 4 \mathrm{H}_{2} \mathrm{O}-1.81 ; \mathrm{Na}_{2} \mathrm{MoO}_{4} \cdot 2\right.$ $\mathrm{H}_{2} \mathrm{O}-0.03 ; \mathrm{H}_{3} \mathrm{BO}_{3}-2.80$ ).

To study HCH destruction $1 \mathrm{mg}$ of $\mathrm{HCH}$ was dissolved in $100 \mathrm{ml}$ of hexane. To dote soil with $\mathrm{HCH}, 50 \mathrm{~g}$ soil samples were transferred into Petri plates and the soils flooded with $10 \mathrm{ml}$ of the $\mathrm{HCH} /$ hexane solution, resulting in the introduction of $100 \mu \mathrm{g}$ of $\mathrm{HCH}$ corresponding to a concentration of $2 \mu \mathrm{g} / \mathrm{g}$ soil. Then, the Petri plates with the doted soil samples were dried until all hexane was evaporated. Then, $2 \mathrm{~g}$ of $\mathrm{NaCl}$ dissolved in water was added to the dried soil to obtain a final salt concentration of $4 \%(\mathrm{wt} / \mathrm{wt})$. Such plates were then inoculated with 8 $\mathrm{ml}$ of cyanobacterial suspensions, mixed and incubated at room temperature. During the incubation time the plates were constantly humidified to maintain growth conditions. In regular time intervals $1 \mathrm{~g}$ of soil was taken from each plate for $\mathrm{HCH}$ analysis.

As a soil we used sierozem, which is a typical Uzbekistan soil. Before the soil was distributed into $50 \mathrm{~g}$ aliquots, it was sterilized by heating for 4 hours at $180^{\circ} \mathrm{C}$.

\subsection{Chemical analyses}

For the detection and quantification of $\mathrm{HCH}$ in soil, $1 \mathrm{~g}$ samples were extracted with $100 \mu \mathrm{l}$ of hexane in an ultrasound bath for 15 minutes. After this treatment hexane was recovered, filtered and dried. Two $\mu 1$ of these hexane extracts were then analyzed by injection into an gas chromatograph equipped with electron capture detection. We used a chromatograph with electron capture detector Agilent Technologies $6890 \mathrm{~N}$. A capillary column HP5, $30 \mathrm{~m}$ length, $0.25 \mathrm{~mm}$ inner diameter was used for separation. Temperature of the injector was $250^{\circ} \mathrm{C}$, oven temperature was initially $70^{\circ} \mathrm{C}$ for $2 \mathrm{~min}$, then rising the temperature to $150^{\circ} \mathrm{C}$ with $25^{\circ} \mathrm{C} / \mathrm{min}$. After this, temperature was increased to $200^{\circ} \mathrm{C}$ with $3^{\circ} \mathrm{C} / \mathrm{min}$, and then to $280^{\circ} \mathrm{C}$ with $80^{\circ} \mathrm{C} / \mathrm{min}$. At last the temperature 
was hold for $10 \mathrm{~min}$ at $280^{\circ} \mathrm{C}$. Pressure in the column was 12.21 psi. Carrier gas was nitrogen. As detector we used an $\mu \mathrm{ECD}$ at a detector temperature of $300^{\circ} \mathrm{C}$.

Detection of $\mathrm{HCH}$ was done according to its retention time. Quantitative analysis of $\mathrm{HCH}$ was performed on the basis of a standard curve with program support of Agilent ChemStation of Agilent Technologies chromatograph $6890 \mathrm{~N}$, by external standard (ESTD) and recalculated to $1 \mathrm{~g}$ of soil.

\subsection{Aldehyde oxidase and xanthine dehydrogenase analysis by native polyacrylamide gel electrophoresis}

Aldehyde oxidase (EC 1.2.3.1) activity was assessed in native polyacrylamide gels by activity staining in gels after electrophoresis in 7\% acrylamide gels (Laemmli, 1970). Gels were run in the absence of SDS at $4^{\circ} \mathrm{C}$. For activity staining gels were immersed in a reaction mixture containing $0.2 \mathrm{M}$ phosphate buffer, $\mathrm{pH} 7.5,0.1 \mathrm{M}$ $\begin{array}{llllllll}\text { Tris- } \mathrm{HCl} & (\mathrm{pH} & 7.5), & 0.1 & \mathrm{mM} & \text { phenazine methosulfate (PMS), } 1 & \mathrm{mM}\end{array}$ 3[4,5-dimethylthiazol-2-yl]-2,5-diphenyltetrazolium-bromide (MTT) and $1 \mathrm{mM}$ substrate indole-3-aldehyde for $10 \mathrm{~min}$ followed by gentle shaking at room temperature.

Xanthine dehydrogenase (EC 1.1.1.204) activity was detected after native gel-electrophoresis using hypoxanthine as a substrate (Mendel and Mbller, 1976), which resulted in the development of specific formazan bands. Aldehyde oxidase and xanthine dehydrogenase activity was estimated by subjecting the strains to salt stress at $300 \mathrm{mM} \mathrm{NaCl}$.

\subsection{Molecular methods}

PCR and sequencing of 16S rRNA genes were done as described previously (Iteman et al., 2000). For Anabaena variabilis $\mathrm{N} 21$ the following primers were chosen: A1 (forward): 5'- GTA TGC TTA CAC ATG CAA GTC GAA CGG -3' and primer A2 (reverse) 5'- TTA CGG CTA GGA CTA CTG GGG TAT CTA -3' (designed from Anabaena variabilis, Gene Bank accession number EF488831). For Nostoc calcicola $\mathrm{N} 25$ the following primers were used: primer N1 (forward) 5'- TGC TGC CTG AAG ATG AGC TCG CGT CTG -3' and primer N2 (reverse) 5'- GAG TGC CCA ACT TAA TGC TGG CAA CTA -3' (designed from Nostoc calcicola, Gene Bank accession number HM573461).

\section{Results}

Two cyanobacterial strains of our culture collections that were able to transform polychlorinated biphenyls in a previous study (Kadirova et al., 2007) were selected. These strains were isolated from Kashkadaryo and Syrdaryo province in Uzbekistan, respectively. The two strains had initially been identified as Anabaena and Nostoc species by classical methods. For sequencing the 16S rRNA genes of the two strains, specific primers for each of the two cyanobacteria species were constructed on the basis of published 16S rRNA gene sequences of Anabaena and Nostoc species. Using these primers we obtained PCR-products from Anabaena variabilis N 21 with 725 bp (Figure 1a), and 813 bp from Nostoc calcicola N 25 (Figure 1b). PCR-products were then sequenced using primers A1, A2 (for Anabaena variabilis N 21) and N1, N2 (for Nostoc calcicola N 25)

Partial nucleotide sequence of the 16S rRNA gene of Anabaena variabilis N 21:

GTATGCTTACACATGCAAGTCGAACGGAATCCTTGGGATTTAGTGGCGGACGGGTGAGTAACGCGT GAGAATCTGGCTTCAGGTCTGGGACAACAGTTGGAAACGACTGCTAATACCGGATGTGCCGAGAG GTGAAAGGCTTGCTGCCTGAAGATGAGCTTGCGTCTGATTAGCTAGTTGGTGGGGTAAGAGCCTAC CAAGGGGACGATCAGTAGCTGGTCTCGAGAGGATGATCAGCCACACTGGGACTGAGACACGGCGC AGACTCCTACGGGAGGCAGCAGTGGGGATTTTTCCGCAATGGGCGAAAGCCTGACGGAGCAATAC CGCGTGAGGGAGGAAGGCTCTTGGGTTGTAAACCTCTTTTCTCAGGGAAGAATAAAATGACGGTAC CTGAGGAATAAGCATCGGCTAACTCCGTGCCAGCAGCCGCGGTAATACGGAGGGATGCAAGCGTT ATCCGGAATGATTGGGCGTAAAGGGTCCGCAGGTGGCTATGTAAGTCTGCTGTTAAATAGTCATGC TCAACATGATCAAGGCAGTGGAAACTACAAGGCTAGAGTGCGTTCGGGGCAGAGGGGAATTCCTG GGTGTAGCGGTGAAATGCGTAGATATCAGGAAGAACACCGGTGGCGATAGCGCTCTGCTAGGCCG CAACTGACACTGAGGGACGAAAGCTAGGGGAGCGAATGGGATAGATACCCCAGTAGTCCTAGCCG TAAACG

Partial nucleotide sequence of the 16S rRNA gene of Nostoc calcicola $\mathrm{N} 25$ :

CCTAGGCGACGATCAGTAGCTGGTCTGAGAGGATGATCAGCCACACTGGGACTGAGACACGGCCC AGACTACCTACGGGAGGCAGCAGTGGGGAATTTTCCGCAATGGGCGAAAGCCTGACGGAGCAATA CCGCGTGAGGGAGGAAGGCTCTTGGGTCGTAAACCTCCTCAGGGAAGAACACAATGACGGTACCT GAGGAATCAGCATCGGCTAACTCCGTGCCAGCAGCCGCGGTATATACGGAGGATAGCAAGCGTTA TCCGGAATGATTGGGCGTAAAGCGTCCGCAGGTGGCTAATGTAGTCTGCTGTTAAAGAGTGAGGCT 
CAACCTCATAAGAGCAGTGGAAACTACATGGCTAGAGTGCGCTTCGGGGCAGAGGGAATTCCTGG TGTAGCGGTGAAATGCGTAGAGATCAGGAAGAACACCGGTGGCGAAAGCGCTCTGCTAGCCGCAT ACTGACACTCATGGACGAAAGCTAGGGGAGCGAATGGGATTAGATACCCCAGTAGTCTAGCCGTA AACGATGGATCCTAGGCGTGGCTTGTATCGACCCGAGCCGTGCCGTAGCTAACGCGTTATAGTATC CCGCCTGGGGAGTACGCAGGCAACTGTGAAACTCAAAGGAATTGACGGGGGCCCGCACAAGCGGT GGAGTATCGTGGTTTAATTCGATTGCAACGCGAAGAACCTTACCAAGACTTGACATGTCGCGAAAC CTTTGTGAAAGCAGAGGGTGCCTTCGGGAGCGCGAACACAGGTGGTGCATGGCTGTCGTCAGCTCG TGTCGTGAGATGTTGGGTTAAGTCCCGCA

Comparative BLASTN analysis showed that the nucleotide sequence of the 16S rRNA gene of Anabaena variabilis N 21 (Uzb1) was 99\% identical with an earlier identified strain of Anabaena variabilis (Gene Bank accession number EF488831). The strain had sequence identity of $93-98 \%$ with other Anabaena species. BLASTN analysis of nucleotide sequence of Nostoc calcicola N 25 (Uzb2) revealed that this strain had high sequence identity $(99 \%)$ with an earlier identified organism, Nostoc calcicola (Gene Bank accession number AM711529).

We analyzed the influence of high concentrations of $\mathrm{NaCl}$ on cell morphology. $\mathrm{NaCl}$ concentrations of up to $500 \mathrm{mM}$ did not affect growth or morphological development of the two blue-green algae (Figure 2c and 2d) compared to growth on low-salt medium (Figure 2a and 2b). Specifically, we surveyed the morphological changes of trichomes of the two cyanobacterial strains by light microscopy. Cells of Anabaena variabilis N 21 in observed trichomes were morphologically not changed in medium with $500 \mathrm{mM} \mathrm{NaCl}$ salinity (Figure 2c) compared to those in medium without additional $\mathrm{NaCl}$ (Figure 2a). However, a smaller cell diameter was observed in trichomes in the high-salinity samples. Also the number of heterocyst was decreased compared with cells growing in low-salt medium. Salt concentration up to $500 \mathrm{mM}$ was not critical for normal growth of the strains. In contrast, $\mathrm{NaCl}$ concentration of $1 \mathrm{M}$ led to deformation of the Anabaena variabilis $\mathrm{N} 21$ cells in the trichomes (Figure 2e), and the periplasmic membrane between the cells in trichomes in Anabaena variabilis $\mathrm{N}$ 21 disappeared. This resulted in the appearance of a long unique cell in Anabaena variabilis N 21 trichomes.

Influence of salinity on the morphology of strain Nostoc calcicola $\mathrm{N} 25$ was considerably different than the effect of salt on Anabaena variabilis N 21. For example, $500 \mathrm{mM} \mathrm{NaCl}$ did not lead to considerable morphological changes of Nostoc calcicola $\mathrm{N} 25$ cells (Figure $2 \mathrm{~b}$ and 2d). At $1 \mathrm{M} \mathrm{NaCl} \mathrm{Nostoc}$ trichomes dissociated into separated single cells and heterocysts completely disappeared (Figure 2f). When cells of both cyanobacteria, that had been subjected to salt stress of $1 \mathrm{M} \mathrm{NaCl}$, were replated on fresh nutrient media without $\mathrm{NaCl}$ the complete recovery of both cyanobacteria Anabaena variabilis N 21 and Nostoc calcicola N 25 was observed.

The two strains Anabaena variabilis N 21 and Nostoc calcicola N 25 were incubated with $\mathrm{HCH}$ at a concentration of $2 \mu \mathrm{g} / \mathrm{g}$ soil with no salt additions as a control or with addition of $4 \% \mathrm{NaCl}$. After four months of incubation of the soil samples with cultures of the tested strains of Anabaena variabilis N 21 and Nostoc calcicola $\mathrm{N} 25$ the concentration of $\mathrm{HCH}$ was decreased from $2 \mu \mathrm{g} / \mathrm{g}$ soil to $14.2 \mathrm{ng} / \mathrm{g}$ soil and $14.3 \mathrm{ng} / \mathrm{g}$ soil, respectively. In contrast, the control with no added microorganisms showed no decrease of the $\mathrm{HCH}$ concentration (Figure 3). Therefore, the two cyanobacterial strains removed $99 \%$ of the introduced HCH within four months under laboratory conditions. This demonstrated $\mathrm{HCH}$ degradation activity in the presence of $4 \%$ $\mathrm{NaCl}$.

It is known that aldehyde oxidase (EC 1.2.3.1) and xanthine dehydrogenase (EC 1.1.1.204) play a role in processes that are responsible for adaptation of living organisms to stress conditions. We therefore analyzed aldehyde oxidase (Figure 4) and xanthine oxidase (Figure 5) activities in the Anabaena variabilis N 21 and Nostoc calcicola $\mathrm{N} 25$ under low-salt and high-salt conditions using a native gel approach. The results show that only one type of aldehyde oxidase was expressed in the cells of Nostoc calcicola N 25. No aldehyde oxidase activity was detected in Anabaena variabilis N 21. In Nostoc calcicola N 25 the activity of aldehyde oxidase was weak under both culturing conditions, without or with $300 \mathrm{mM} \mathrm{NaCl}$ (Figure 4). Testing for xanthine dehydrogenase on native gels revealed the presence of one single form of the enzyme both in Anabaena variabilis $\mathrm{N} 21$ and Nostoc calcicola $\mathrm{N} 25$ (Figure 5). Activity of xanthine dehydrogenase of both strains was much higher than that of aldehyde oxidase. While we could not detect differences in the activity of aldehyde oxidase with or without added salt, the activity of xanthine dehydrogenase was increased under salt stress in the Nostoc strain. From our obtained data it can be concluded that, in the cells of Nostoc calcicola N 25 xanthine dehydrogenase is synthesized in response to salt stress. 


\section{Discussion}

Cyanobacteria respond very rapidly to salinity in their environment. Salinity induced three prominent types of modification in nitrogen-fixing cyanobacteria (Apte \& Bhagwat, 1989; Bhagwat \& Apte, 1989). First, the synthesis of several proteins was inhibited, especially in the salt-sensitive strains; second, the synthesis of certain proteins was significantly upregulated; and third, synthesis of a specific set of proteins was induced de novo by salinity stress. Proteins which were selectively synthesized or induced de novo during salt stress, were tentatively called the salt-stress proteins.

It is known that survival and growth of bacteria depend on the salt concentration of the environment. Influence of salt on bacterial cells is stipulated by osmotic binding of water, leaking of salt into the cytoplasm and/or specific actions of specific ions in the protoplasm. At high salt concentrations water is less available for bacterial cells. In our study, salt concentrations of up to $500 \mathrm{mM}$ did not inhibit growth of the two investigated cyanobacteria, but at $\mathrm{NaCl}$ concentration of $1 \mathrm{M}$ deformation of the Anabaena variabilis $\mathrm{N} 21$ cells in trichomes was seen. However, because we could recover live cells from $1 \mathrm{M} \mathrm{NaCl}$ medium we conclude that $1 \mathrm{M} \mathrm{NaCl}$ is not a lethal salinity for the strains but impairs growth and assumingly physiological characteristics. Other studies have shown that several salt tolerant Azotobacter and Azospirillum strains can survive up to $1.5 \mathrm{M} \mathrm{NaCl}$ not loosing their nitrogen fixing activity (Rasulov, 2010; Shakirov, 2006). At the same time at $0.8 \mathrm{M} \mathrm{NaCl} 75-80 \%$ acetylene-reductase activity, which is a proxy for nitrogen fixing activity, was preserved. Comparing our results with other studies in which cyanobacteria were analyzed for their salt tolerance (Manickam et al., 2006; Rasulov et al., 2010), Anabaena variabilis N 21 and Nostoc calcicola N 25 transformed HCH far more effectively in salt stress than other described cyanobacteria, even catabolizing introduced $\mathrm{HCH}$ in the presence of $4 \% \mathrm{NaCl}$.

Biodegradation of $\mathrm{HCH}$ has been studied in soil, slurry and culture media but very little information exists on biodegradation in salt affected environment by bacteria, particularly by cyanobacteria. Monitoring studies by some authors revealed that in some cases industrial areas may be contaminated with all major isomers of $\mathrm{HCH}$. The analytical results confirmed that accumulation depends on the plants species, soil and climate conditions. As is found for most organic compounds, $\mathrm{HCH}$ degradation in soil occurs at moderate temperatures, at near neutral $\mathrm{pH}$ and at both low and high moisture contents (Phillips et al., 2005). Information on the effects of salinity on biodegradation is scattered and less well investigated in regard to cyanobacteria. In our previous research we tested several mesophylic strains of Bacillus to degrade PCBs (polychlorinated biphenyls) in salt-affected soils under aerobic conditions (Rasulov et al., 2010) and found that some strains were able utilize PCBs even in high concentration of $\mathrm{NaCl}(4 \%)$. Several microbes have been reported to degrade $\mathrm{HCH}$ (Ito et al., 2007; Lal et al., 2008; Manickam et al., 2006; Nagata et al., 2007; Wu et al., 2007). Also the biodegradation of diverse pesticides, insecticides and other organic compounds by cyanobacteria has been demonstrated. Some cyanobacteria degrade phenylcarbamyte herbicides, such as propham and chloropham, to aniline and chlorine derivatives (Gromov, 1996). Also many other complex hydrocarbons were transformed by cyanobacteria. Cyanobacteria of the genera Anabaena, Phormodium, or Oscillatoria degrade different aromatic compounds (Radwan \& Al-Hasan, 2002). Microcoleus chthonoplastes, Phormidium corium, and Synechocystis sp. were found to utilize up to $25 \%$ of added n-alkanes within 7-10 days (Safonova et al., 2004). The marine cyanobacterium Phormidium valderianum BDU 20041 was able to dwell and grow in the presence of chlorpyrifos (O,O-diethyl-O-[3,5,6-trichloro-2-pyridyl] phosphorothioate), a phosphorothioate insecticide, at a concentration of 45 ppm (Palanisami et al., 2009).

As it was shown in Figure 3 the strains normally catabolized $\mathrm{HCH}$ even in the presence of $\mathrm{NaCl}$. It is worth noting that Anabaena variabilis N 21 was more active than Nostoc calcicola N 25. After two months of incubation with Anabaena variabilis N 21 the concentration of $\mathrm{HCH}$ was decreased by $207.5-242.3 \mathrm{ng} / \mathrm{g}$ soil from an initial amount of $2041.6 \mathrm{ng} / \mathrm{g}$ soil introduced. After four months, $\mathrm{HCH}$ concentrations were decreased to $12.2-14.2 \mathrm{ng} / \mathrm{g}$ soil.

Our results allowed us to conclude that the tested cyanobacterial strains either transformed $\mathrm{HCH}$ to volatile compounds or completely mineralized them. The amount of $\mathrm{HCH}$ introduced into the cyanobacterial cultures was relatively high with $2 \mu \mathrm{g} / \mathrm{g}$ soil. Nevertheless, the strains clearly showed their potential to survive these high concentrations of $\mathrm{HCH}$ and that they were able to degrade them at high efficiency even at high salt concentrations of $4 \% \mathrm{NaCl}$. Both these characteristics are important for the practical application of cyanobacteria for the bioremediation of soils in Uzbekistan. The high resistance towards $\mathrm{HCH}$ would be important for survival in highly contaminated soil, which in addition of $\mathrm{HCH}$ also often contains PCBs and DDT in Uzbekistan. Further studies will investigate the survival of cyanobacteria in a mix of different chloroorganics. 
While the degradation of $2 \mu \mathrm{g} \mathrm{HCH}$ per gram soil in this laboratory study was accomplished within 1-4 months, we expect that the removal in the field will take longer. However, a substantial reduction of HCH load over a period of several vegetation periods would be feasible and worth pursuing. According to the results shown in this report, the analyzed cyanobacterial strains can be recommended for their use as biopreparations for the remediation of saline soils contaminated with chloroorganics.

\section{References}

Alexander, M. (1999). Biodegradation and bioremediation, 2nd ed. Academic Press, San Diego, Calif.

Apte, S. K., \& Bhagwat, A. A. (1989). Salinity-stress-induced proteins in two nitrogen-fixing Anabaena strains differentially tolerant to salt. Journal of Bacteriology, 171, 909-915.

Bhagwat, A. A., \& Apte, S. K. (1989). Comparative analysis of proteins induced by heat shock, salinity, and osmotic stress in the nitrogen-fixing cyanobacterium Anabaena sp. strain L-31. Journal of Bacteriology, 171, 5187-5189.

Forkutsa, I., Sommer, R., Shirokova, Y., Lamers, J., Kienzler, K., Tischbein, B, .... Vlek, P. (2009). Modeling irrigated cotton with shallow groundwater in the Aral Sea Basin of Uzbekistan: II. Soil salinity dynamics. Irrigation Science, 27, 319-330. http://dx.doi.org/10.1007/s00271-009-0149-0

Gromov, B. V. (1996). Цианобактерии в биосфере (Cуanobacteria in the biosphere). Соросовский образовательный журнал (Soros Educational Journal), 9, 33-39.

Iteman, I., Rippka, R., Tandeau de Marsac, N., \& Herdman, M. (2000). Comparison of conserved structural and regulatory domains within divergent $16 \mathrm{~S}$ rRNA-23S rRNA spacer sequences of cyanobacteria. Microbiology, $146,1275-1286$.

Ito, M., Prokop, Z., Klvana, M., Otsubo, Y., Tsuda, M., Damborsky, J., \& Nagata, Y. (2007). Degradation of beta-hexachlorocyclohexane by haloalkane dehalogenase $\mathrm{LinB}$ from gamma-hexachlorocyclohexane-utilizing bacterium Sphingobium sp. MI1205. Archives of Microbiology, 188, 313-325. http://dx.doi.org/10.1007/s00203-007-0251-8

Kadirova, G. H., Halilov, I. M., Kim, A. A., Dzhuraeva, G. A., \& Dzhabbarova, O. I. (2007). Деструкция полихлорированных бифенилов - цианобактериями (in Russian - Degradation of polychlorinated biphenyls by cyanobacteria). ДАН АН РУ (Reports of the Academy of Sciences of the Republic of Uzbekistan), 3, 63-66.

Kumari, R., Subudhi, S., Suar, M., Dhingra, G., Raina, V., Dogra, C., ... Lal, R. (2002). Cloning and characterization of lin genes responsible for the degradation of hexachlorocyclohexane isomers by Sphingomonas paucimobilis strain B90. Applied and Environmental Microbiology, 68, 6021-6028. http://dx.doi.org/10.1007/BF00201651

Laemmli, U. K. (1970). Cleavage of structural proteins during the assembly of the head of bacteriophage T4. Nature, 227, 680-685. http://dx.doi.org/10.1038/227680a0

Lal, R., Dadhwal, M., Kumari, K., Sharma, P., Singh, A., Kumari, H., ... Jindal, S. (2008). Pseudomonas sp. to Sphingobium indicum: a journey of microbial degradation and bioremediation of hexachlorocyclohexane. Indian Journal of Microbiology, 48, 3-18. http://dx.doi.org/10.1007/s12088-008-0002-9

Lypez-Gomollyn, S., Sevilla, E., Bes, M. T., Peleato, M. L., \& Fillat, M. F. (2009). New insights into the role of Fur proteins: FurB (All2473) from Anabaena protects DNA and increases cell survival under oxidative stress. The Biochemical Journal, 418, 201-207. http://dx.doi.org/10.1042/BJ20081066

Manickam, N., Mau, M., \& Schlцmann, M. (2006). Characterization of the novel HCH-degrading strain, Microbacterium sp. ITRC1. Applied Microbiology and Biotechnology, 69, 580-588. http://dx.doi.org/10.1007/s00253-005-0162-z

Mendel, R. R., \& Mbller, A. (1976). A common genetic determination of xanthine dehydrogenase and NR in $N$. tabacum. Biochemie Physiologie Pflanzen, 170, 538-541.

Mertens, B., Boon, N., \& Verstraete., W. (2006). Slow-release inoculation allows sustained biodegradation of gamma-hexachlorocyclohexane. Applied and Environmental Microbiology, 72, 622-627. http://dx.doi.org/10.1128/AEM.72.1.622-627.2006

Nagata, Y., Endo, R., Ito, M., Ohtsubo, Y., \& Tsuda, M. (2007). Aerobic degradation of lindane (gamma-hexachlorocyclohexane) in bacteria and its biochemical and molecular basis. Applied Microbiology and Biotechnology, 76, 741-752. http://dx.doi.org/10.1007/s00253-007-1066-x 
Nagata, Y., Futamura, A., Miyauchi, K., \& Takagi, M. (1999). Two different types of dehalogenases, LinA and LinB, involved in gamma-hexachlorocyclohexane degradation in Sphingomonas paucimobilis UT26 are localized in the periplasmic space without molecular processing. Journal of Bacteriology, 181, 5409-5413.

Palanisami, S., Prabaharan, D., \& Uma, L. (2009). Fate of few pesticide-metabolizing enzymes in the marine cyanobacterium Phormidium valderianum BDU 20041 in perspective with chlorpyrifos exposure. Pesticide Biochemistry and Physiology, 94, 68-72. http://dx.doi.org/10.1016/j.pestbp.2009.03.003

Phillips, T. M., Seech, A. G., Lee, H., \& Trevors, J. T. (2005). Biodegradation of hexachlorocyclohexane (HCH) by microorganisms. Biodegradation, 16, 363-392. http://dx.doi.org/10.1007/s10532-004-2413-6

Radwan, S., \& Al-Hasan, R. (2002). Oil pollution and Cyanobacteria., p. 307-319. In B. Whitton and M. Potts (ed.), The Ecology of Cyanobacteria. Springer Netherlands. http://dx.doi.org/10.1007/0-306-46855-7_11

Rasulov, B. A. (2010). The bacteria of Azotobacter genus - producers of phytohormones in salinity conditions. PhD thesis, Tashkent,

Rasulov, B. A., Kim, A. A., Adrian, L., \& Yadgarov, K. T. (2010). Biodegradation of tritium labeled polychlorinated biphenyls (PCBS) by local salt tolerant mesophylic Bacillus strains. Journal of Environmental Protection, 1, 420-425. http://dx.doi.org/10.4236/jep.2010.14048

Safonova, E., Kvitko, K. V., Iankevitch, M. I., Surgko, L. F., Afti, I. A., \& Reisser, W. (2004). Biotreatment of industrial wastewater by selected algal-bacterial consortia. Engineering in Life Sciences, 4, 347-353. http://dx.doi.org/10.1002/elsc.200420039

Shakirov, Z. S. (2006). Azospirilli of Uzbekistan soils and their influence on growth and development of wheat plants. Plant and Soil, 283, 137-145. http://dx.doi.org/10.1007/s11104-005-5690-x

Shirokova, Y., Forkutsa, I., \& Sharafutdinova, N. (2000). Use of electrical conductivity instead of soluble salts for soil salinity monitoring in Central Asia. Irrigation and Drainage Systems, 14, 199-206. http://dx.doi.org/10.1023/a:1026560204665

Thomas, J. C., Berger, F., Jacquier, M., Bernillon, D., Baud-Grasset, F., Truffaut, N., ... Simonet, P. (1996). Isolation and characterization of a novel gamma-hexachlorocyclohexane-degrading bacterium. Journal of Bacteriology, 178, 6049-6055.

van Elsas, J. D., Dijkstra, A. F., Govaert, J. M., \& van Veen, J. A. (1986). Survival of Pseudomonas fluorescens and Bacillus subtilis introduced into two soils of different texture in field microplots. FEMS Microbiology Letters, 38, 151-160. http://dx.doi.org/10.1016/0378-1097(86)90046-7

van Veen, J. A., van Overbeek, L. S. \& van Elsas, J. D. (1997). Fate and activity of microorganisms introduced into soil. Microbiology and Molecular Biology Reviews, 61, 121-135.

von Elsas, J. D., \& Heijnen, C. E. (1990). Methods for the introduction of bacteria into soil: A review. Biology and Fertility of Soils, 10, 127-133. http://dx.doi.org/10.1007/bf00336248

Wu, J., Hong, Q., Han, P., He, J., \& Li, S. (2007). A gene linB2 responsible for the conversion of beta-HCH and 2,3,4,5,6-pentachlorocyclohexanol in Sphingomonas sp. BHC-A. Applied Microbiology and Biotechnology, 73, 1097-1105. http://dx.doi.org/10.1007/s00253-006-0579-z 

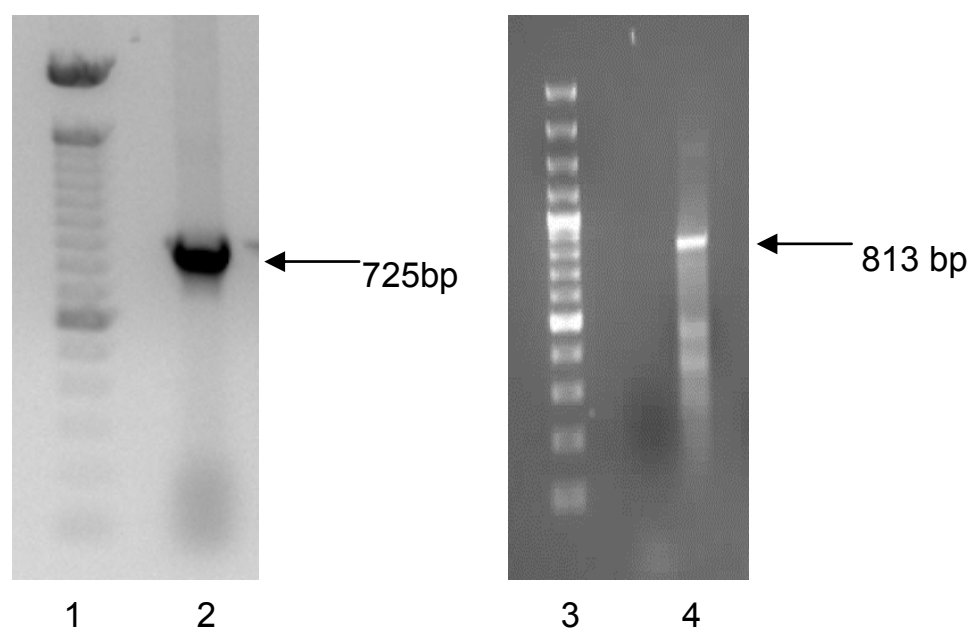

Figure 1. Electrophoretic separation of PCR-products of DNA of Anabaena variabilis N 21 and Nostoc calcicola $\mathrm{N} 25$ on 1.5\% agarose gels. Lanes 1 and 3. Marker DNA ladder $100 \mathrm{bp}$. Lane 2. PCR-product of Anabaena variabilis N 21; Lane 4. PCR-product of Nostoc calcicola $\mathrm{N} 25$
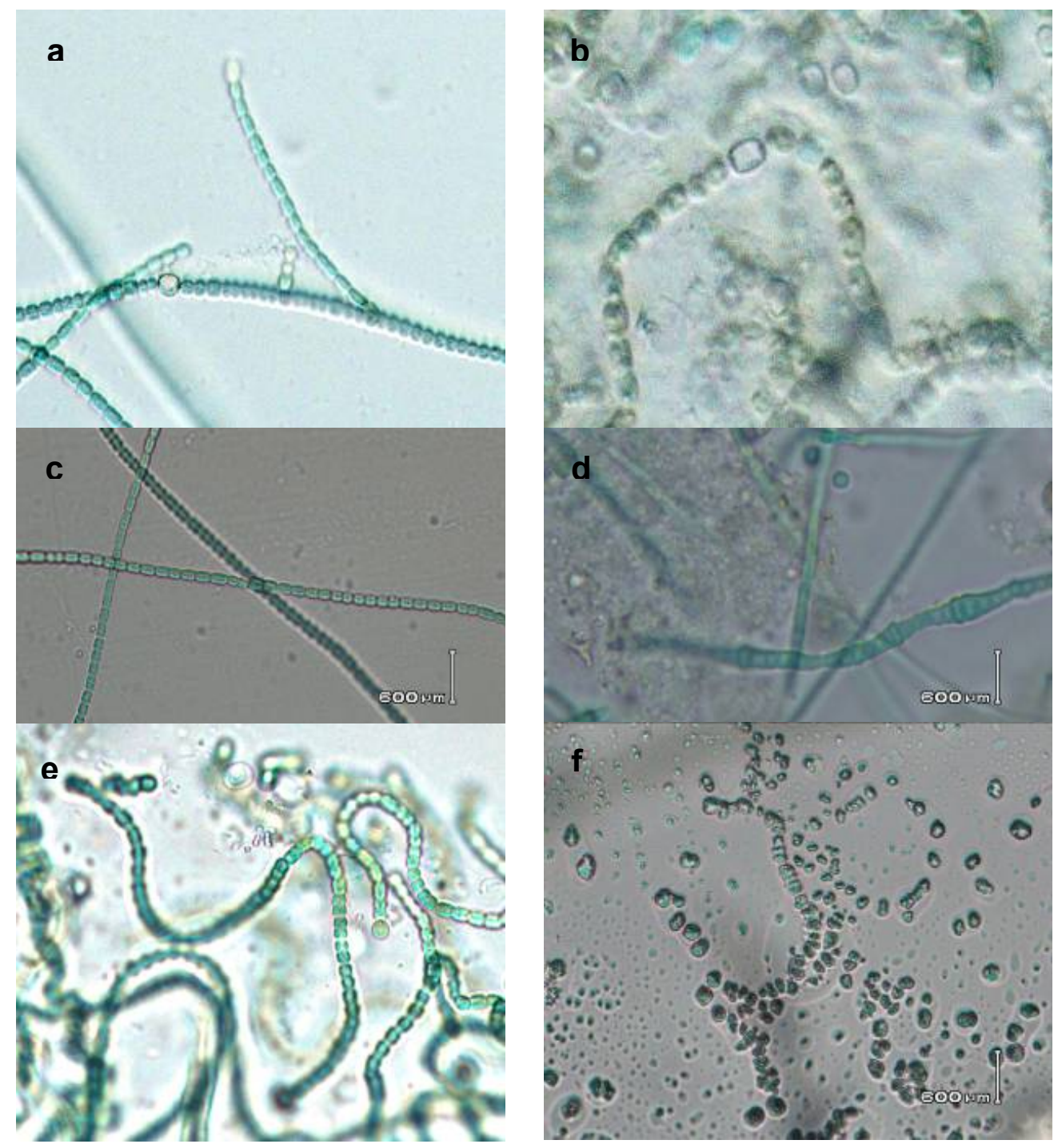

Figure 2. Microscopic pictures of Anabaena variabilis N 21 (a, c and e) and Nostoc calcicola $\mathrm{N} 25$ (b, d, and f) 
in different $\mathrm{NaCl}$ concentrations. a and b: low salt-concentration, c and d: $500 \mathrm{mM} \mathrm{NaCl}$; e and f: $1 \mathrm{M} \mathrm{NaCl}$
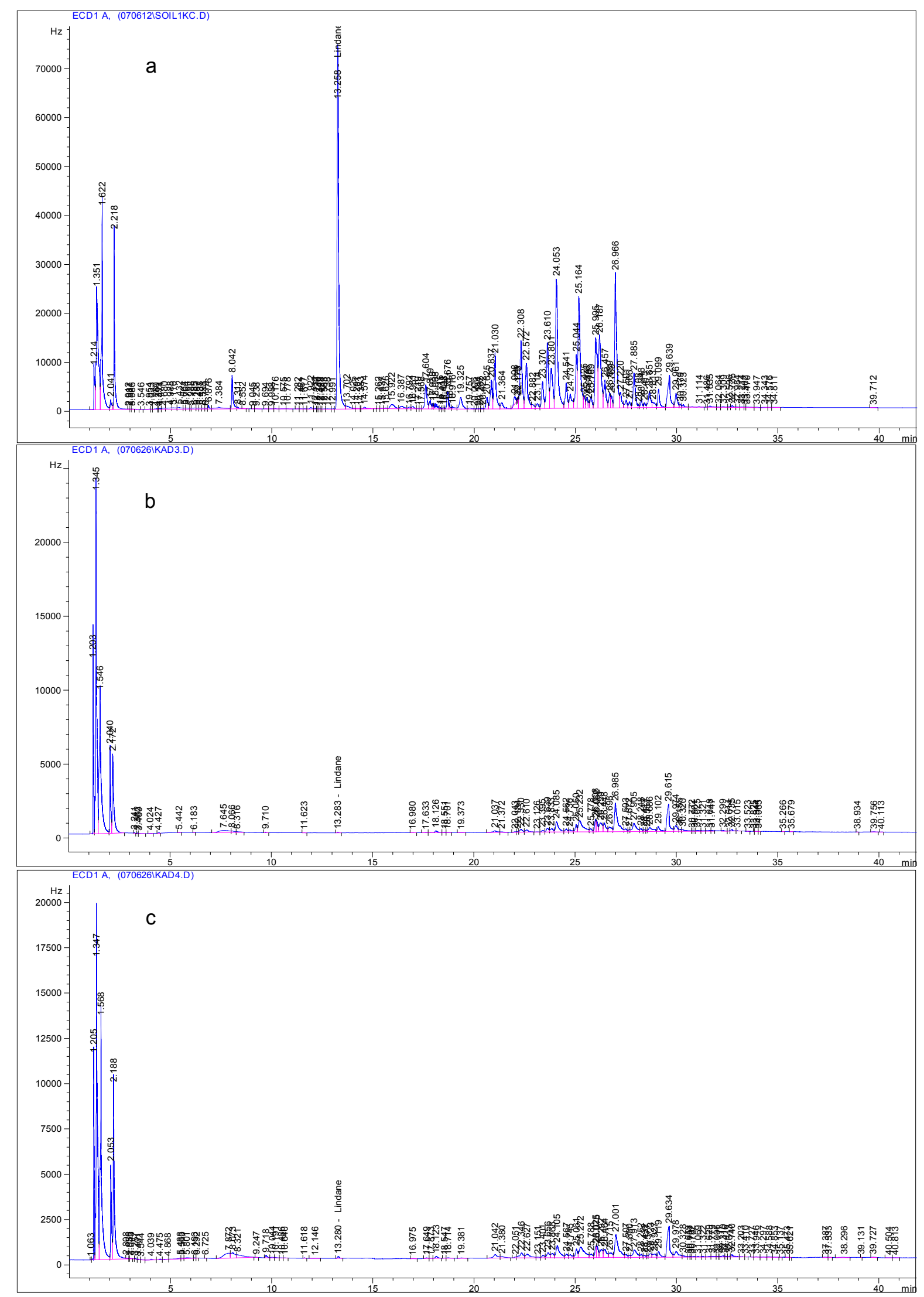

Figure 3. Chromatograms of hexane extracts from soils initially amended with $\mathrm{HCH}$ (lindane) and $4 \% \mathrm{NaCl}$. All extractions were done after four months of incubation. a) Control soil not amended with cyanobacterial strains; b) 
Soil inoculated with Anabaena variabilis N 21; c) Soil inoculated with Nostoc calcicola N 25

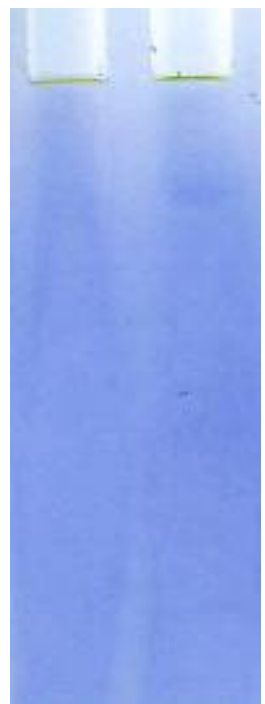

1
2

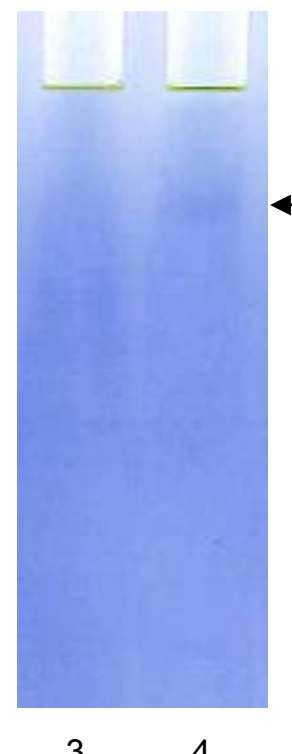

34

\author{
Aldehyde \\ $\longleftarrow$ oxidase \\ activity
}

Figure 4. Aldehyde oxidase activity of Anabaena variabilis N 21 and Nostoc calcicola N 25 in medium with or without high-salt concentration: Lane 1: Anabaena variabilis $\mathrm{N} 21$ without $\mathrm{NaCl}$; lane 2: Nostoc calcicola $\mathrm{N} 25$ without NaCl; lane 3: Anabaena variabilis N 21 with $300 \mathrm{mM} \mathrm{NaCl}$; lane 4: Nostoc calcicola N 25 with $300 \mathrm{mM}$ $\mathrm{NaCl}$
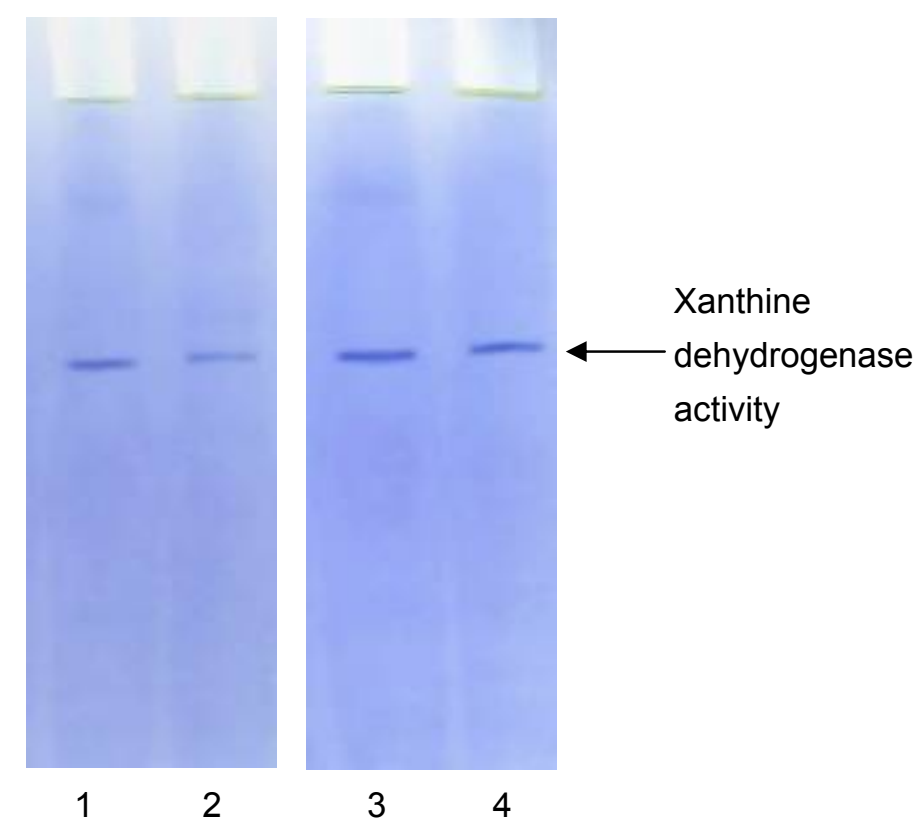

Figure 5. Xanthine dehydrogenase activity of Anabaena variabilis $\mathrm{N} 21$ and Nostoc calcicola $\mathrm{N} 25$, in low-salt vs. high-salt conditions. Lane1: Anabaena variabilis N 21 without $\mathrm{NaCl}$; lane 2: Nostoc calcicola $\mathrm{N} 25$ without $\mathrm{NaCl}$; lane 3: Anabaena variabilis $\mathrm{N} 21,300 \mathrm{mM} \mathrm{NaCl}$; lane 4: Nostoc calcicola $\mathrm{N} 25,300 \mathrm{mM} \mathrm{NaCl}$ 